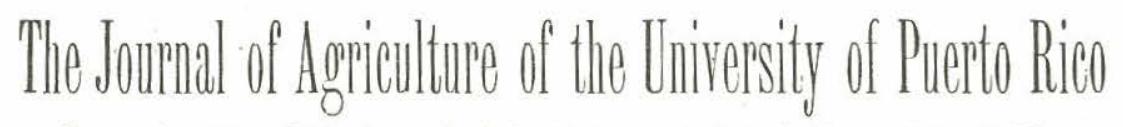

In continuation of The Journal of the Department of Agriculture of Puerto Rico

Published Quarterly: January, A pril, July and 0etober of each year.

Merville T. CoOK, Editor

VoL. XXI

JANUARY 1937

No. 1

\title{
ANCIENT RECORDS OF BIRDS FROIM THE ISLAND OF ST. CROIX WITH OBSERVATIONS ON FXTINCT AND LIVING BIRDS OF PUERTO RICO
}

By ALEXANDER WeTMORE

United States National Museum

During the summer of 1934 Dr. L. J. Korn, working under the Museum of the American Indian, Heye Foundation, of New York City, excavated a kitchen midden on St. Croix in the Virgin Islands, from which he obtained a considerable collection of bones of birds. Identification of this material has revealed 23 species of birds, including a number of records of value as the following list will show. The collection has been of particular interest in view of my earlier studies of bones from middens on this same island from excavations made by $\mathrm{Mr}$. Theodoor De Booy. ${ }^{1}$ And, further, has been of importance in connection with some of the extinct species found also on Puerto Rico. The additional information regarding these former Puerto Rican birds is of definite value in connection with the fauna of that island.

The site was at a place known as Concordia on the south coast about one and one half miles east of Southwest Cape, which marks the extreme southwestern extension of the island. The midden was located about 400 yards inland from the beach and was about 30 inches in depth. Bones of mammals, birds, turtles and fishes were found to the bottom of the deposit, with more birds at the center level than elsewhere.

As with most material of this kind the exact age of it is not certain, except that it antedates the period of discovery, since the deposits do not include objects of European origin. The bird bones are in good condition except for breakage, and are entirely free of animal matter. It is assumed that they have an antiquity of between 500 and 800 years. The assemblage gives a definite picture of the larger species in the avifauna of St. Croix before the forests and lagoons were despoiled by Caucasian intrusion.

1 See Proc. U. S. Nat. Mus., vol. 54, 1918, pp. 513-522, pl. 82. 
The material is preserved in the collections of the U. S. National Museum. Drawings illustrating certain specimens have been made for me by Mr. Sidney Prentice.

\section{PROCELLARIIDAE}

Puffinus Lherminieri Lesson. Audubon's Shearwater.

Two humeri with the extremities somewhat broken represent this species without question. Audubon's shearwater was found earlier in De Booy's material from a midden on Magen's Bay on the north coast of St. Thomas, and is known to breed on Saba Island two and one half miles south of the western end of St. Thomas. The present record is the first report of it from the island of St. Croix.

\section{PELECANIDAE}

Pelecanus occidentalis Linnaeus. Brown Pelican.

Represented by parts of two humeri and an ulna.

\section{SULIDAE}

\section{Sula dactylatra Lesson. Blue-faced Booby.}

A cranium, measuring $40 \mathrm{~mm}$. in transverse diameter across the occipital region, from its size is identified without question as this species. The specimen represents the only record for the blue-faced booby from this area, and is a record of considerable importance as it indicates a greater range for the species in prehistoric times than at present. While the blue-faced booby nested formerly in the Bahamas it has not been reported from the Virgin Islands or Puerto Rico. The nearest modern colonies of which I have record are on the Alacran reefs of Yucatán, the Grenadines and Los Hermanos Islands on the coast of Venezuela.

\section{Sula leucogaster (Boddaert). Brown Booby.}

Represented by a cranium, fragmentary humeri, ulnae, coracoids, a metacarpal and a tibio-tarsus, this species is easily recognized. The tibio-tarsus is distinctly larger than in S. piscator. The brown booby occurs today along the shores of St. Croix and Puerto Rico.

\section{Sula piscator (Linnaeus). Red-footed Booby.}

A fragmentary humerus, a metacarpal and an ulna come from this species which in general is distinguished from the brown booby 
by rather definite skeletal characters. The humerus which is almost the same in size in the two, in the present species has the ridge for the insertion of the latissimus dorsi muscle placed farther from the upper margin of the bone than in Sula leucogaster. The ulna and metacarpal are more slender.

\section{ARDEIDAE}

ARDEA Herodias Linnaeus. Great Blue Heron.

A broken pelvis, parts of three tibio-tarsi, and a broken femur come from this species, easily distinguished from other herons by larger size.

Nyctanassa violacea (Linnaeus). Yellow-crowned Night Heron.

This common heron is represented by fragments of five humeri and two femora.

\section{PHOENICOPTERIDAE}

Phoentcopterus ruber Linnaeus. Flamingo.

Next to De Booy's Rail this species is the most common bird in the present collection, indicating that it was of regular occurrence, and calling to mind the statement of A. E. Newton" that "large bands of some species of flamingo $\mathrm{x} \times \mathrm{x} \times$ are said to have formerly visited St. Croix periodically, and even of late years a few seem to have been occasionally observed." There has been no other report of this bird until now, and these bones seem to be the only specimens extant from St. Croix. The species seems to have been considerably reduced in numbers comparatively soon after the coming of white men.

\section{ANATIDAE}

Chen sp.

The proximal half of a left humerus represents a goose of this genus, agreeing in size and outline with males of Chen hyperborea hyperborea (Pallas). It may be noted however that in the lesser snow goose and the blue goose the head of the humerus shows no differences, so that this fragment is not identified to species. The specimen is of definite interest in that it is the first indication of these birds in the Virgin Islands. As the lesser snow goose formerly came regularly to $\mathrm{Cuba}^{1}$ it is probable that the St. Croix bird was of that form.

2 Barbour, T., Mem. Nuttall Ornith. Club, 1923, p. 42. 
In my account of the Birds of Porto Rico and the Virgin Islands ${ }^{1}$ I gave uncertain records of white geese for Puerto Rico under the name of the Greater Snow Goose. It seems more probable in view of the greater range and more extended migration of the lesser snow goose that these notes properly relate to the latter form.

\section{Mareca americana (Gmelin). Baldpate.}

This duck, rare in migration in the West Indies, is represented by the distal end of a humerus. It is still found at the proper season on St. Croix as H. A. Beatty ${ }^{2}$ records one killed on Krause Lagoon on November 11, 1921.

\section{Dafila bahamensis (Linnaeus). Bahama Pintail.}

Several humeri and a few other bones attest the presence of this resident form.

\section{RALLIDAE}

RaLlus longtrostris Boddaert. Clapper Rail.

Five complete tibio-tarsi and eight fragments of the same bone indicate the presence of this inhabitant of mangrove swamps. It is of interest to record that Beatty ${ }^{3}$ records this bird as "common in the mangroves bordering Krause Lagoon, the only place on the island where they are found." This locality is on the southern part of St. Croix not far from the kitchen midden where the bones noted above were obtained.

\section{Ionornis martinica (Linnaeus). Purple Gallinule.}

The lower end of a metatarsus comes from this handsome species which has not been recorded previously from St. Croix though it is of regular occurence in Puerto Rico. The metatarsus in this species is easily distinguished from that of the Florida gallinule by the larger, deeper and more distinctly marked depression for the hallux, and by the pronounced trough-like excavation of the posterior face. Toward the head the inner margin of the bone becomes a thin plate, entirely unlike other species of its family that I have examined, except Porphyrio, which has the same general conformation of this bone.

${ }^{1}$ New York Acad. Sci., Scient. Surv. Porto Rico and Virgin Islands, vol. 9, 1927, p. 306 .

2 Journ. Dept. Agric. Porto Rico, vol. 14, July, 1930, p. 137.

3 Journ. Dept. Agric. Porto Rico, vol. 14, July, 1930, p. 139. 


\section{Nesotrochis debooyi Wetmore. De Booy's Rail.}

The abundance of this curious rail and its importance as a food item among the St. Croix Indians is attested by the quantity of bones from the present deposit, there being remains of at least a dozen individuals and probably more. This rail and the flamingo are in fact the species most commonly represented. The rail material includes numerous femora and tibio-tarsi, several of them complete, and two humeri. One of the latter (figs, 1-2) is complete and shows the characters of this bone perfectly, previous specimens available having been more or less damaged. Though the humerus in all rails is relatively small, in Nesotrochis, when compared with other parts of the skeleton, this bone seems especially weak. The complete specimen has the following measurements: Total length 62.9, transverse breath of head 13.0, transverse of distal end 10.0, transverse breadth of shaft at center $4.2 \mathrm{~mm}$. There can be no doubt that Nesotrochis did not have the power of active flight. The humerus mentioned is so important that drawings are given to show its characters, the specimen from Cueva San Miguel, Puerto Rico, that I have illustrated previously ${ }^{1}$ having been defective at the lower end and on the crista superior due to corrosion from the soil in which it was preserved.

Most interesting in the present collection of bones of this species are the four specimens representing the metatarsus, which has been known previously only from a fragment, found in Puerto Rico, of the distal third of the bone. One of the present bones is complete except for slight breakage on the edge of the inner trochlea, another has the trochlea broken, and the remaining two are fragments of the head and the adjacent shaft. The complete specimen (figs. 3-7) is strong with well developed trochlea which are relatively heavy, with those at the sides less elevated above the central one than is usual in rails.

The facet for articulation of the hind toe is faintly indicated, less so than in any of the other rails examined, seeming to point to a slight and little functional development of that digit. The head is broad and strong and the shaft relatively heavy. The entire bone is decidedly reduced in length and strengthened in form when placed beside the metatarsus of such a species as Aramides. Following are

${ }^{2}$ Bull. Amer. Mus. Nat. Hist., vol. 46, May 22, 1932, figs. 8-9; New York Acad. Sci. Scient. Surv. Porto Rico and Virgin Islands, vol. 9, pt. 3, p. 34. 
measurements of the complete specimen: Total length 71.5, transversebreadth of head 13.0, transverse breadth of trochlea 14.6, transverse breadth of shaft at center $5.9 \mathrm{~mm}$. The broken specimen measures. $13.5 \mathrm{~mm}$. across the trochlea and $6 \mathrm{~mm}$. across the center of the shaft. One of the fragments in only $5.4 \mathrm{~mm}$. across the shaft.

The addition of the complete metatarsus to the skeletal elements. of this species alters somewhat my earlier beliefs ${ }^{1}$ as to the affinities. of Nesotrochis among living rails. Principally from evidence obtained from the femur and tibio-tarsus I have believed it to be "a. highly specialized off-shoot from the primitive stock that has produced Aramides and closely allied (but not ancestral) to that groupof species." The metatarsus in the relative position of the trochlea. and the form of the talon and adjacent parts is nearest the subfamily Gallinulinae. The tibio-tarsus has the head somewhat likethat of Aramides while the distal end inclines toward the gallinules. Characters of the femur are much obscured by its heavier form sothat this bone offers nothing of importance in considering relationships, while the humerus is so highly peculiar as to show no definiteaffinities.

After careful consideration and fresh comparisons of the additional material listed above I am led now to consider Nesotrochis: a specialized form of the subfamily Gallinulinae, that so far as the New World is concerned has no close relatives. Curiously enough the modern species that I have seen whose skeleton is most similar to Nesotrochis is Tribonyx mortierii Du Bus of the distant island of Tasmania. Proportions of the lower limb are quite similar in the two species considered, though femur, tibio-tarsus and metatarsus are distinctly heavier in Tribonyx. The humerus is about the same in size in both. There is suggestion in these similarities not so much of close affinity as of a former wide distribution of a group of non-volant, cursorial forms of habits quite different from those of aquatic or marsh inhabiting species. While Nesotrochis may be now considered an aberrant member of the subfamily Gallinulinae there is suggestion that it may merit subfamily recognition when more is known of it.

It appears from information at hand even more certainly than before that De Booy's Rail was not a pond, lake or marsh frequenting bird that waded habitually in water, but instead a courser that

${ }^{1}$ Bull. Amer. Mus. Nat. Hist., vol. 46, 1922, p. 311. 
ran over drier ground. It will be recalled that it has been found on St. Thomas, St. Croix and Puerto Rico. It is now known from the larger lower limb bones, part of the pelvis and the humerus. Additional discoveries will be awaited with interest.

\section{LARIDAE}

Thalasseus maximus (Boddaert). Royal Tern.

An assortment of wing bones come from this common species.

Anoüs stolidus (Linnaeus). Noddy Tern.

Newton in 1859 thought that the noddy came to St. Croix but had no definite report for it.. A humerus from the midden collection is the first definite record for the island.

\section{COLUMBIDAE}

Columba leucocephalus Linnaeus. White-crowned Pigeon.

This common species is represented by an ulna and a humerus.

Columba squamosa Bonnaterre. Sealed Pigeon.

An ulna, similar to that of the white-crowned pigeon but larger, is identified as this species.

\section{Zenaida zenaida (Bonaparte). Zenaida Dove.}

This is a common species on St. Croix, of which four humeri and two ulnas have been identified. One humerus and the two ulnas are smaller than skeletons of this species at present in the National $\mathrm{Mu}$ seum collections, but the difference is considered within the range of individual variation.

Peters ${ }^{1}$ recently has treated $Z$. zenaida as a subspecies of $Z$ enaida aurita. While the two are clearly representative of the same type of dove it is my feeling that the uniform differences between them are considerable enough to warrant separation of the two groups as distinct species. I have therefore listed these bones under the name Zenaida zenaida. The differences between the two may be summarized as follows:

Zenaida zenaida. Adult, grayer, paler above, below deeper reddish brown, slaty gray on abdomen and distinctly darker on under

${ }^{1}$ Auk, 1927, p. 535; Condor, 1934, p. 215. 
tail-coverts; juvenile, paler above than adult, duller, less reddish brown, below, with under tail-coverts dark as in the adult.

Range, Bahamas and Greater Antilles (including Puerto Rico) to St. John, Tortola, Salt Island, and Virgin Gorda in the Virgin group.

Zenaida AURITA. Adult, darker and more rufescent above, paler below, with abdomen and under tail-coverts decidedly lighter; juvenile, darker above than adult, darker also on neck and chest but with under tail-coverts light.

Range, Saba, St. Bartholomew and St. Eustatius to Barbadoes.

Both show darker and lighter extremes due to the extent of brown in the plumage and an occasional individual of aurita has a considerable reddish suffusion over the abdomen and under tailcoverts, but such are separated from zenaida without difficulty. It is especially noteworthy that the differences between the two are as pronounced in juvenile individuals as in adults.

The Anegada Passage seems to be the dividing line in range of these two species.

I may note that earlier ${ }^{1}$ I have listed Zenaida aurita from St. Croix on the basis of a record by Cory ${ }^{2}$. I now believe that this is erroneous and that this report by Cory refers properly to $Z$. zenaida. No other records of aurita have come from this island. The report of aurita from Virgin Gorda also I believe to be in error.

\section{PSITTACIDAE}

Ara AUtocthones sp. nov.

Characters.-Tibio-tarsus similar to Ara tricolor Bechstein ${ }^{3}$ but larger in transverse width; form slender when compared with larger macaws.

Type, U. S. Nat. Mus. No. 343033, left tibio-tarsus, from Concordia, southwestern St. Croix, Virgin Islands, collected in kitchen midden deposits in 1934 by Dr. L. J. Korn.

Remarlss.-The left tibio-tarsus of a small macaw (figs. 8-9) is the most unexpected find in the entire collection, as there has been no previous report of such birds from St. Croix. The specimen is from

1 Scient. Surv. Porto Rico and Virgin Islands, vol. 9, 1927, p. 398.

2 Auk, 1891, p. 48.

${ }^{3}$ A [ra] tricolor Bechstein, Allg. Ueb. Vög., vol. 4, pt. 1, 1811, p. 64, pl. 1. 
an individual that, while fully grown, was still immature as the bone is slightly spongy about the extremities. In size it is intermediate between such large species as Ara macao and A. militaris and the small A. severa. Its slender proportions and the more elongated ridges about the proximal end serve to show that it is truly a macaw and not an Amazon parrot like the large Amazona imperialis.

When compared with the tibio-tarsus of living macaws it is marked by slender form and a slightly greater posterior development of the proximal end. Aside from this its only peculiarity seems to rest in its dimensions which do not fall within those of any other species known.

It measures as follows: Total length 77.7, transverse breath across distal end 9.4, smallest transverse diameter of shaft $3.9 \mathrm{~mm}$.

In the following list there are given the forms of macaws that have been recorded from the West Indies, with their distribution:

Ara tricolor Bechstein. Cuba, Isle of Pines.

Ara gossei Rothschild. Jamaica.

Ara erythrocephala Rothschild. Jamaica.

Ara sp. Haiti.

Ara guadeloupensis Clark. Guadeloupe, Martinique.

Ara martinica (Rothschild). Martinique.

Ara atwoodi Clark. Dominica.

Ara erythrura Rothschild. One of the West Indian Islands.

Anadorhynchus purpurascens Rothschild. Guadeloupe.

It is obvious that the relationship of the bird from St. Croix to any of the above is difficult to establish. There is only one, Ara tricolor, of which specimens are extant, the rest having been described or recorded on the basis of indefinite, uncertain and incomplete accounts of early travelers.

The tibio-tarsus from St. Croix is from a slightly larger bird than the Cuban macaw as shown by comparison with the lower end of the tibiotarsus in two skins of Ara tricolor in the National Museum collections. Further than this there is little that may be said about it except that it has the peculiar value of being the only specimen now known of any other species of the group from the West Indies, and that it is the only record for the region from which it comes, the nearest report for a macaw to the west being from Haiti, (none being known from Puerto Rico), and from the east and south from 
Guadeloupe. While many uncertainties accompany the bone from St. Croix, particularly its affinity with the forms that have been described from the accounts of early travellers, it has seemed best to designate it by name rather than to leave it without such identification.

\section{STRIGIDAE}

Gymnasio nudipes Newtoni (Lawrence). Newton's Owl.

Two femora, one complete and one broken tibio-tarsus, and part of a humerus come from at least two individuals. Identification to subspecies is made on geographic grounds as these bones do not differ from a skeleton of G. n. nudipes from Puerto Rico.

\section{CORVIDAE}

Corvus leucognaphalus Daudin. Puerto Rican Crow.

With eight more or less complete humeri and other bones of this crow in the present collection its former abundance in St. Croix is established, especially since this is the third site on the island from which bones of these birds have been obtained. De Booy secured it near the mouth of Salt River, and Mrs. Hugo Hark has forwarded specimens from a midden on the Richmond Estate near Christiansted. There can be no reasonable doubt that it was native on St. Croix and that it ranged the primitive forests of that island in some numbers. That it was a resident is rendered more certain by the fact that a number of the bones are from young birds that had either come from the nest or were only recently on the wing.

\section{Convus Pummis Wetmore. Lesser Puerto Rican Crow.}

This extinct crow, described from an ulna obtained in a cave deposit near Morovís, Puerto Rico, has been known until now only from the type specimen. It is of great interest to report a complete tibio-tarsus (figs. 10-12) from St. Croix that, on the basis of analogy in size, must be ascribed to this species, thus affording at one and the same time information on an additional skeletal element, and an extension of range to another island.

One of the principal characters in distinguishing Corvus pumilis has been size, the ulna being distinctly smaller than that of $C$. leucognaphalus and slightly larger than that of $C$. palmarum. This same degree of difference is found in the tibio-tarsus from St. Croix. 
In three skeletons of leucognaphalus from Hispaniola the length of the tibio-tarsus varies from 82.8 to $85.1 \mathrm{~mm}$. In seven palmarum from the same island this bone ranges from 71.9 to $77.4 \mathrm{~mm}$. The specimen from St. Croix measures $78.1 \mathrm{~mm}$. and as it carries about the same proportion of greater size as the ulna it is considered to be pumilis. It is appreciably heavier in shaft and extremities than the largest palmarum at hand so that there is no difficulty in separating it from that species.

Remembering that two forms of crow, one large and one small, range today in Cuba and Hispaniola, and that the finding of the extinct pumilis in Puerto Rico gave similar representation for that island, it is quite natural to discover the same combination on St. Croix. While pumilis is near palmarum additional skeletal material of both indicates that they are distinct.

The present find adds another interesting species to the avifauna of St. Croix. 
Figs. 1-2.-Right humerus of De Booy's Rail, Nesotrochis debooy?, about natural size.

Figs. 3-5.-Left metatarsus of De Booy's Rail, Nesotrochis debooyi, about natural size.

Figs. 6-7.- Outline of head and trochleae of metatarsus of De Booy's Rail, Nesotrochis debooyi, about natural size.

Figs. 8-9.-Left tibio-tarsus of St. Croix macaw, Ara autocthones, about natural size.

Figs. 10-12.-Right tibio-tarsus of Lesser Puerto Rican Crow, Corvus pumilis, about natural size. 
PLATE I
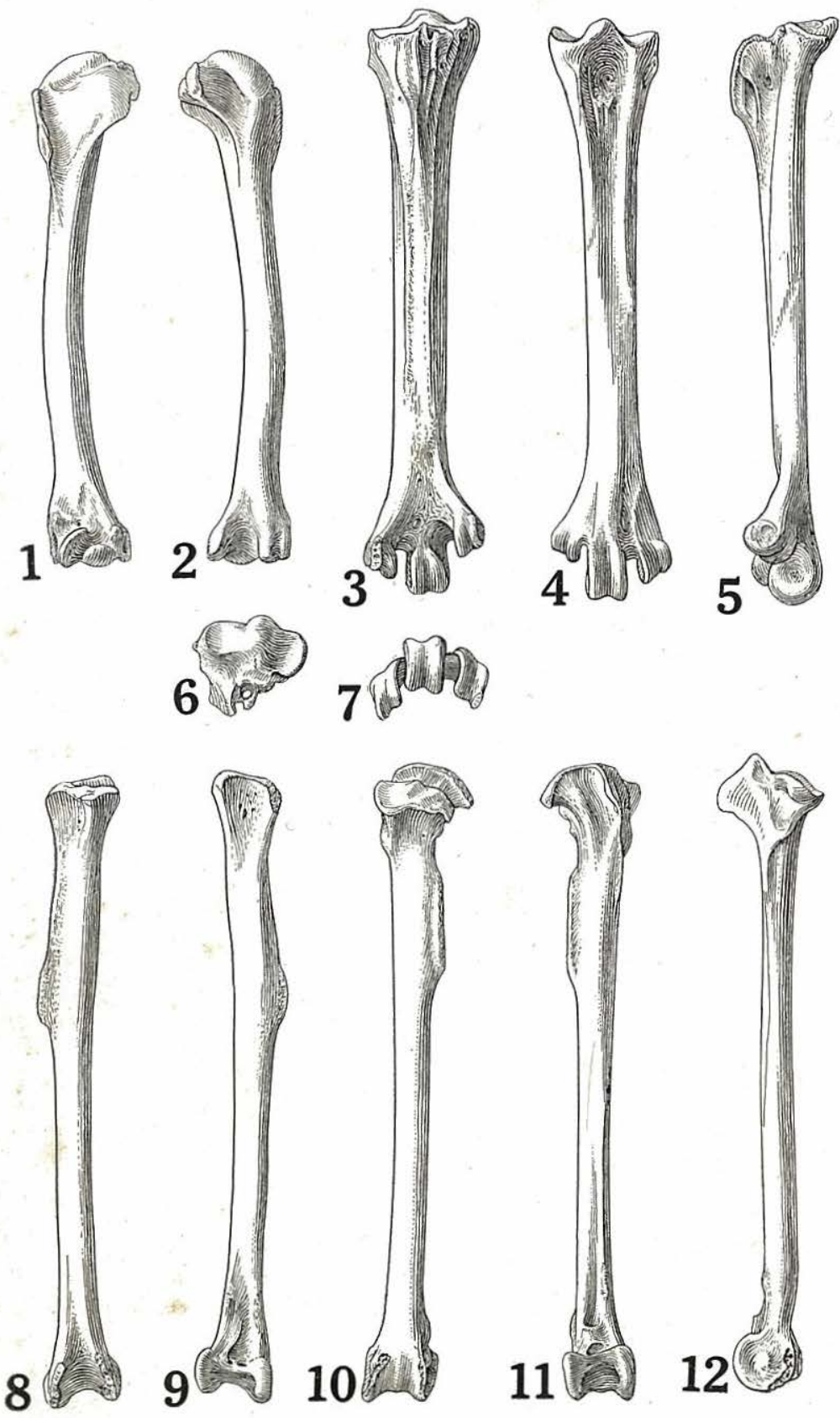